\title{
EKOHOMIKA
}

Ribogospod. nauka Ukr., 2020; 2(52): 78-85

DOI: https://doi.org/10.15407/fsu2020.02.078

УДК 639.3.043:[338.45:639.371.2]
Received 16.02.20

Received in revised form 28.03.20

Accepted 24.04.20

\section{ECONOMIC EFFICIENCY OF GROWING EARLY JUVENILES OF RUSSIAN STURGEON (ACIPENSER GUELDENSTAEDTII BRANDT \& RATZEBURG, 1833) WITH THE INTRODUCTION OF INACTIVATED BAKER'S YEAST IN THEIR DIET}

M. Simon, seemann.sm@gmail.com, Institute of Fisheries NAAS, Kyiv H. Kurinenko, annazakharenko@ukr.net, Institute of Fisheries NAAS, Kyiv N. Kolesnik, kolenataleo@gmail.com, Institute of Fisheries NAAS, Kyiv

Purpose. To determine the main parameters of economic efficiency of the use of inactivated baker's yeast as a biologically active additive in the diet of early juveniles of Russian sturgeon.

Methodology. The calculations were carried out according to generally accepted methods for economic studies. For economic analysis, we used the actual parameters of economic activity in current industrial aquaculture of Ukraine with the use of RAS, as well as prices for 2015-2016 on relevant materials, products and means of production.

Findings. The economic efficiency of introducing 5\% and 15\% (by weight of the main feed) inactivated baker's yeast into the diet of early juvenile Russian sturgeon grown in the RAS has been established. These concentrations allow achieving more than $70 \%$ profitability and reducing the prime cost of one fish to 1.72-1.74 UAH, thereby ensuring high, as compared with other options for feeding, parameters as net (372.96 UAH and 366.86 UAH) and attributable profit (873.0 UAH and 876.0 UAH).

Originality. For the first time, the parameters of economic efficiency of introducing $4(5 \%, 10 \%$, $15 \%, 40 \%$ of the weight of the main feed) concentrations of inactivated baker's yeast into the diet of juvenile Russian sturgeon for 28 days, from 25 to 53 days after hatching were analyzed.

Practical Value. The study results have both theoretical and practical importance and can be used in further studies aimed at optimizing the cultivation of juvenile sturgeons in RAS and adjusting existing feeding schemes on fish farms.

Keywords: economic efficiency, juvenile fish, fish feeding, RAS, Russian sturgeon, baker's yeast.

\section{ЕКОНОМІЧНА ЕФЕКТИВНІСТЬ ВИРОЩУВАННЯ РАННЬОЇ МОЛОДІ POCIЙСЬКОГО OCETPA (ACIPENSER GUELDENSTAEDTII BRANDT \& RATZEBURG, 1833) ЗА ВЕДЕННЯ ДО РАЦІОНУ ІНАКТИВОВАНИХ ПЕКАРСЬКИХ ДРІЖДЖІВ}

М. Ю. Симон, seemann.sm@gmail.com, Інститут рибного господарства НАAН, М. Київ

Г. А. Куріненко, annazakharenko@ukr.net, Інститут рибного господарства НАAН, м. Київ

Н. Л. Колесник, kolenataleo@gmail.com, Інститут рибного господарства НАAН, м. Київ

(C) M. Simon, H. Kurinenko, N. Kolesnik, 2020 
Мета. Визначити основні показники економічної ефективності застосування інактивованих пекарських дріжджів у якості біологічно-активної добавки в раціоні ранньої молоді російського осетра.

Методика. Викладені розрахунки здійснено за загальноприйнятими в економіці методиками. Для економічного аналізу використані фактичні показники господарської діяльності в сучасній індустріальній аквакультурі України, що передбачає використання УзВ, а також ціни 2015-2016 рр. на відповідні матеріали, різноманітні види продукції та засоби виробництва.

Результати. Встановлено економічну доцільність введення 5 та 15\% від маси основного корму інактивованих пекарських дріждів до раціону молоді російського осетра. Дані концентрації дозволяють досягти рівня рентабельності у понад $70 \%$ та знизити собівартість 1 екземпляра до 1,72-1,74 грн, тим самим забезпечуючи найвищі, з-поміж інших варіантів годівлі, показники як чистого (372,96 та 366,86 грн), так і умовного прибутку (873,0 ma 876,0 грн).

Наукова новизна. Вперше проаналізовано показники економічної ефективності введення чотирьох (5, 10, 15, 40\% від маси основного корму) концентрацій інактивованих пекарських дріжджів до раціону молоді російського осетра впродовж 28 діб, з 25 по 53 добу після викльову з ікри.

Практична значимість. Результати досліджень мають як теоретичне, так $i$ практичне значення, та можуть бути використані в подальших дослідженнях щодо оптимізації вирощування молоді осетрових видів риб в УзВ або для корегування вже існуючих схем годівлі на господарствах.

Ключові слова: економічна ефективність, молодь риб, годівля риб, УзВ, російський осетер, пекарські дріжджі.

\section{ЭКОНОМИЧЕСКАЯ ЭФФЕКТИВНОСТЬ ВЫРАЩИВАНИЯ РАННЕЙ МОЛОДИ РУССКОГО ОСЕТРА (ACIPENSER GUELDENSTAEDTII BRANDT \& RATZEBURG, 1833) ПРИ ВВЕДЕНИИ В РАЦИОН ИНАКТИВИРОВАННЫХ ПЕКАРСКИХ ДРОЖЖЕЙ}

М. Ю. Симон, seemann.sm@gmail.com, Институт рыбного хозяйства НАAН, г. Киев А. А. Куриненко, annazakharenko@ukr.net, Институт рыбного хозяйства НАAН, г. Киев

Н. Л. Колесник, kolenataleo@gmail.com, Институт рыбного хозяйства НАAН, г. Киев

Цель. Определить основные показатели экономической эффективности применения в качестве биологически активной добавки инактивированных пекарских дрожжей в рационе ранней молоди русского осетра.

Методика. Изложенные расчеты осуществлены по общепринятым в экономике методикам. Для экономического анализа использованы фактические показатели хозяйственной деятельности в современной индустриальной аквакультуре Украины, предусматривающей использование УзВ, а также цены 2015-2016 г2. на соответствующие материалы, виды продукции и средства производства.

Результаты. Установлена экономическая целесообразность введения 5 и 15\% от массы основного корма, инактивированных пекарских дрожжей в рацион молоди русского осетра, выращиваемой в системе УзВ. Данные концентрации позволяют достичь более чем 70\% уровня рентабельности и снизить себестоимость 1 экземпляра до 1,72-1,74 грн, тем самым обеспечивая высокие, по сравнению с другими вариантами кормления, показатели как чистой (372,96 и 366,86 грн ) так и условной прибыли (873,0 и 876,0 грн).

Научная новизна. Впервые проанализированы показатели экономической эфрективности введения четырех (5, 10, 15, 40\% от массы основного корма) концентраций 
инактивированных пекарских дрожжей в рацион молоди русского осетра в течение 28 суток, с 25 по 53 сутки после выклева из икры.

Практическая значимость. Результаты исследований имеют как теоретическое, так и практическое значение. Они могут быть использованы в дальнейших исследованиях по оптимизации выращивания молоди осетровых видов рыб в УзВ и для корректировки уже существующих схем кормления на хозяйствах.

Ключевые слова: экономическая эфрективность, молодь рыб, кормление рыб, УзВ, русский осетр, пекарские дрожњ.

\section{PROBLEM STATEMENT AND ANALYSIS OF LAST ACHIEVEMENTS AND PUBLICATIONS}

Currently, economic efficiency is perhaps the most important factor determining the feasibility of certain improvements in the production process in fish farming.. First of all, this is due to the fact that in the conditions of a free market economy existing in Ukraine, any establishment should be profitable, providing profit to the owner. At the same time, the latter is almost incapable of influencing the final level of the value of its products, as it is determined by complex market forces. However, the producer of fishery products, in our case - the juvenile Russian sturgeon, is able to influence its cost. The latter directly depends on how intensively the enterprise uses production resources, improves technics and technology, organizes production [1-4].

Therefore, the development of sturgeon farming in Ukraine is not possible without the intensification of fish farming in general and increasing the efficiency of RAS in particular. In turn, achieving the results in these areas of aquaculture allows optimizing the feeding of fish with feed, in particular through the introduction of biologically active additives in the diet. For example, in the course of the study it was found that the introduction of inactivated baker's yeast into the diet of juvenile Russian sturgeon can improve the quality of fish, which is interconnected with the level of survival, and therefore interconnected with the number of individuals that can be sold at the end of the growing period, thereby affecting the profitability of production.

\section{HIGHLIGHT OF THE EARLIER UNRESOLVED PARTS OF THE GENERAL PROBLEM. AIM OF THE STUDY}

Improving the economic efficiency of measures to intensify fish farming in general, and the use of RAS in particular, necessitates the constant search for new methods and approaches to problems solving. The latter are mainly related to the quality and survival of juvenile fish, especially during its transition to compound feeding $[5,6]$. In turn, this encourages the improvement of existing feed formulations and experiments with biologically active additives.

The purpose of the study, based on the above, was to determine the main parameters of economic efficiency (prime cost, profitability) of inactivated baker's yeast, as a biologically active additive, in the diet of early juvenile Russian sturgeon. 


\section{MATERIALS AND METHODS}

The outlined calculations were performed according to generally accepted methods in economics. For the economic analysis, we used the actual parameters of economic activity in current industrial aquaculture of Ukraine based on the use of RAS, as well as the prices of 2015-2016 for the relevant materials, various types of products and means of production.

The material for assessing the cost-effectiveness of the introduction of inactivated baker's yeast in the diet were the early juveniles of Russian sturgeon, which were fed manually every 3 hours by this biologically active additive mixed with the main starter feed. In total, 2 series of experiments were performed. In the 1st series of the experiment, we investigated the efficiency of introduction of $10 \%$ and $40 \%$ (by weight of the main feed) of inactivated baker's yeast, in the 2 nd series - 5\% and $15 \%$. The duration of the experiment was 28 days, from 25 to 53 days from hatching.

Mathematical processing of the material was performed using MS Excel.

The calculation of the economic efficiency of growing Russian sturgeon was carried out according to the recommendations [7,8]. The economic effect was calculated by the formula:

$$
\begin{aligned}
& L P=\frac{\Pi}{3} \times 100, \text { where: } \\
& P \text { - level of profitability, } \% \\
& \Pi \text { - profit, UAH.; } \\
& 3 \text { - prime cost, costs associated with growing fish, UAH. }
\end{aligned}
$$

The structure of the prime cost of fish included the main costs associated with the production of products at fish farms [7-9].

\section{STUDY RESULTS AND THEIR DISCUSSION}

According to the results of the study of the cultivation of early juveniles of Russian sturgeon with the introduction of inactivated baker's yeast into the diet as a new method of intensification of fish farming, an economic assessment of their use at different concentrations was given. The calculation of the economic efficiency of the use of inactivated baker's yeast was based on the total cost of feeds, taking into account the partial replacement of feed with a biologically active additive - this microorganism.

Thus, it was found that under equal conditions (labor costs, feed and the number of fish stocking material) $40 \%$ replacement of feed weight by inactivated baker's yeast negatively affected the final results of cultivation, leading to lower a number of individuals sold compared to control (table 1).

At the same time, when $5 \%, 10 \%$ and $15 \%$ of feed weight were replaced by inactivated baker's yeast, the opposite result was observed - the number of individuals that could be sold at the end of the growing period increased relative to control. When comparing all studied options, the best result in the cultivation of early juveniles of Russian sturgeon was ensured by the use of $5 \%$ and $15 \%$ of inactivated baker's yeast in the main feed. 
ECONOMIC EFFICIENCY OF GROWING EARLY JUVENILES OF RUSSIAN STURGEON (ACIPENSER GUELDENSTAEDTII BRANDT \& RATZEBURG, 1833) WITH THE INTRODUCTION IN THE DIET INACTIVATED BAKER'S YEAST

Table 1. The cost of labor and material resources for the cultivation of early juveniles of Russian sturgeon with the introduction of inactivated baker's yeast into their diet

\begin{tabular}{|c|c|c|c|c|c|c|}
\hline \multirow[b]{2}{*}{ Indicators } & \multicolumn{3}{|c|}{ Experiment 2015} & \multicolumn{3}{|c|}{ Experiment 2016} \\
\hline & $\begin{array}{l}\text { Con- } \\
\text { trol } \\
\text { №1 }\end{array}$ & $\begin{array}{l}\text { Experimen- } \\
\text { tal group } \\
\text { №2 (10\% } \\
\text { yeast) }\end{array}$ & $\begin{array}{c}\text { Experimen- } \\
\text { tal group } \\
\text { №4 (40\% } \\
\text { yeast) }\end{array}$ & $\begin{array}{l}\text { Con- } \\
\text { trol } \\
\text { №2 }\end{array}$ & $\begin{array}{c}\text { Experimen- } \\
\text { tal group } \\
\text { №1 (5\% } \\
\text { yeast) }\end{array}$ & $\begin{array}{l}\text { Experimen- } \\
\text { tal group } \\
\text { №3 (15\% } \\
\text { yeast) }\end{array}$ \\
\hline $\begin{array}{l}\text { Purchased fish seeds, } \\
\text { larvae, individuals }\end{array}$ & 300 & 300 & 300 & 300 & 300 & 300 \\
\hline $\begin{array}{l}\text { Number of individuals } \\
\text { sold, individuals }\end{array}$ & 233 & 247 & 218 & 269 & 291 & 292 \\
\hline Feed supply: & & & & & & \\
\hline compound feed, g & 372.9 & 357.3 & 195.6 & 304.6 & 359.3 & 401.8 \\
\hline baker's yeast, $\mathrm{g}$ & - & 34.6 & 130.5 & - & 21.0 & 70.9 \\
\hline Labor costs, person & 2 & 2 & 2 & 2 & 2 & 2 \\
\hline
\end{tabular}

According to the conditions of production, i.e. use of a RAS, the largest (over $50 \%$ of the total) costs were associated with the purchase of fish seeds, the levers of influence on the price of which were almost absent (except when fish were grown at the same farm). Thus, in all variants of the experiments, the purchase costs of Russian sturgeon larvae ranged from 52.72\% (experimental group №4) to $55.45 \%$ (control group №2).

A similar situation was observed for other production costs, which included labor costs and electricity and water supplies - they were also determined by the general market conditions and ranged from $36.4 \%$ (experimental group №4) to $37.75 \%$ (control group №1) (Fig. 1).

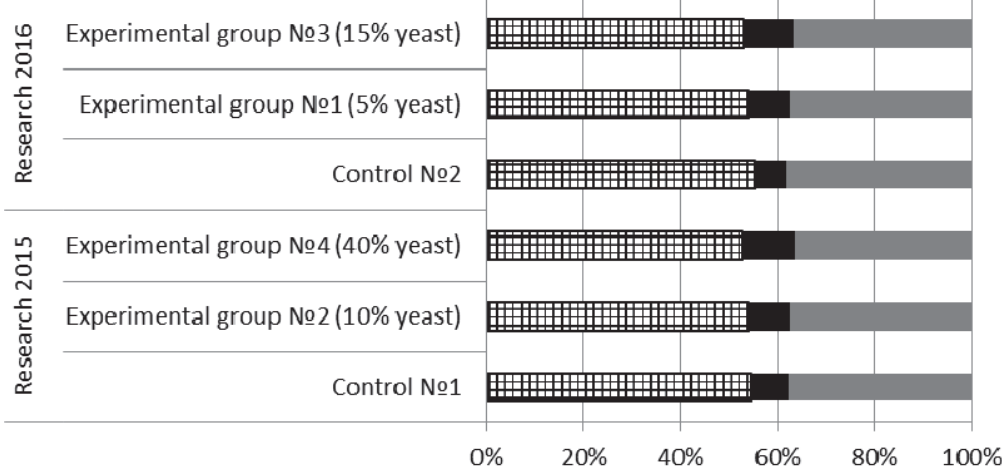

$\square$ The cost of fish stocking material (larvae), \%

- Feed costs, $\%$

- Other production costs, \%

Fig. 1. The ratio of the share of costs for fish seeds, feed and other production from the total, when growing juveniles of Russian sturgeon 
Instead, the share of feed costs can be adjusted by the producer, but not always reducing this cost item leaded to production optimization. For example, feed costs for growing juveniles of Russian sturgeon ranged from $6.25 \%$ (control group №2) to $10.88 \%$ (experimental group №4) and did not correlate with the quality of farmed individuals (Table 2).

Table 2. The prime cost of growing early juveniles of Russian sturgeon with the introduction of inactivated baker's yeast into their diet *

\begin{tabular}{|c|c|c|c|c|c|c|}
\hline \multirow[b]{2}{*}{ Indicators } & \multicolumn{3}{|c|}{ Experiment 2015} & \multicolumn{3}{|c|}{ Experiment 2016} \\
\hline & $\begin{array}{c}\text { Control } \\
\text { №1 }\end{array}$ & \begin{tabular}{|c|} 
Experi- \\
mental \\
group №2 \\
$(10 \%$ \\
yeast)
\end{tabular} & $\begin{array}{c}\text { Experi- } \\
\text { mental } \\
\text { group №4 } \\
\text { (40\% } \\
\text { yeast) }\end{array}$ & $\begin{array}{c}\text { Control } \\
\text { №2 }\end{array}$ & \begin{tabular}{|c|} 
Experi- \\
mental \\
group №1 \\
(5\% \\
yeast)
\end{tabular} & $\begin{array}{c}\text { Experi- } \\
\text { mental } \\
\text { group №3 } \\
\text { (15\% yeast) }\end{array}$ \\
\hline $\begin{array}{l}\text { The cost of fish seeds } \\
\text { (larvae), UAH / individuals }\end{array}$ & 0.9 & 0.9 & 0.9 & 0.9 & 0.9 & 0.9 \\
\hline $\begin{array}{l}\text { The cost of fish seeds } \\
\text { (larvae), UAH }\end{array}$ & $\frac{270}{54.7^{* *}}$ & $\frac{270}{54.2^{* *}}$ & $\frac{270}{52.72^{* *}}$ & $\frac{270}{55.45} *$ & $\frac{270}{54.0^{* *}}$ & $\frac{270}{53.04^{* *}}$ \\
\hline $\begin{array}{l}\text { The cost of } 1 \mathrm{~kg} \text { of } \\
\text { compound feed, UAH }\end{array}$ & 100 & 100 & 100 & 100 & 100 & 100 \\
\hline Total feed costs, UAH & $\frac{37.29}{7.55^{* *}}$ & $\frac{41.85}{8.4^{* *}}$ & $\frac{55.72}{10.88^{* *}}$ & $\frac{30.46}{6.25^{* *}}$ & $\frac{43.65}{8.73^{* *}}$ & $\frac{52.75}{10.36^{* *}}$ \\
\hline compound feed & 37.29 & 35.73 & 19.56 & 30.46 & 39.93 & 40.20 \\
\hline baker's yeast & - & 6.12 & 23.10 & - & 3.72 & 12.55 \\
\hline Salary, UAH & $\frac{118.6}{24.02^{* *}}$ & $\frac{118.6}{23.8^{* *}}$ & $\frac{118.6}{23.15^{* *}}$ & $\frac{118.6}{24.36^{* *}}$ & $\frac{118.6}{23.71^{* *}}$ & $\frac{118.6}{23.29 * *}$ \\
\hline $\begin{array}{l}\text { Wage taxes, UAH (19.5\% of } \\
\text { the wages) }\end{array}$ & $\frac{23.13}{4.68^{* *}}$ & $\frac{23.13}{4.64^{* *}}$ & $\frac{23.13}{4.51^{* *}}$ & $\underline{23.13}$ & $\frac{23.13}{4.62^{* *}}$ & $\frac{23.13}{4.54^{* *}}$ \\
\hline Electricity, UAH & $\frac{24.3}{4.92^{* *}}$ & $\frac{24.3}{4.87^{* *}}$ & $\frac{24.3}{4.74^{* *}}$ & $\frac{24.3}{4.99 * *}$ & $\frac{24.3}{4.85^{* *}}$ & $\frac{24.3}{4.77^{* *}}$ \\
\hline Water use, UAH & $\frac{16.8}{3.4^{* *}}$ & $\frac{16.8}{3.37^{* *}}$ & $\frac{16.8}{3.28^{* *}}$ & $\frac{16.8}{3.45^{* *}}$ & $\frac{16.8}{3.35^{* *}}$ & $\frac{16.8}{3.29^{* *}}$ \\
\hline Amortization & $\frac{3.56}{0.72^{* *}}$ & $\frac{3.56}{0.71^{* *}}$ & $\frac{3.56}{0.69^{* *}}$ & $\frac{3.56}{0.73^{* *}}$ & $\frac{3.56}{0.71^{* *}}$ & $\frac{3.56}{0.69^{* *}}$ \\
\hline In total, UAH & 493.68 & 498.24 & 512.11 & 486.85 & 500.04 & 509.14 \\
\hline
\end{tabular}

Note. * all financial calculations, except for the cost of feed made on the basis of the number of juveniles of Russian sturgeon in 50 thousand individuals;

** \% ratio to total costs of cultivation.

Thus, the largest (over 50\%) part of the cost of juveniles of Russian sturgeon was the cost of fish seeds, and the smallest (up to $11 \%$ ) - the cost of feeds. At the same time, among other production costs, the most significant, among other items, were deductions for wages. They ranged from $23.15 \%$ (experimental group №4) to $24.02 \%$ (control group №1). The cost of electricity was comparable to that of water use, ranging from $4.77 \%$ (experimental group №3) to 4.99\% (control group №2) versus 3.28\% (experimental group №4) and 3.45\% (control group №2), respectively. Amortization was the least of all the expenditure for growing early juveniles of Russian sturgeon in the RAS. 
Based on the above mentioned, the economic efficiency of the use of inactivated baker's yeast in the feeding early juveniles of Russian sturgeon determined the level of profitability (Table 3 ).

Table 3. Financial results of growing early juveniles of Russian sturgeon with the introduction of inactivated baker's yeast into their diet

\begin{tabular}{|l|c|c|c|c|c|c||}
\hline \multirow{2}{*}{ Indicators } & \multicolumn{4}{|c|}{ Experiment 2015 } & \multicolumn{3}{c||}{ Experiment 2016 } \\
\cline { 2 - 7 } & $\begin{array}{c}\text { Control } \\
\text { №1 }\end{array}$ & $\begin{array}{c}\text { Experi- } \\
\text { mental } \\
\text { group No2 } \\
\text { (10\% yeast) }\end{array}$ & $\begin{array}{c}\text { Experi- } \\
\text { mental } \\
\text { group No4 } \\
\text { (40\% yeast) }\end{array}$ & $\begin{array}{c}\text { Control } \\
\text { №2 }\end{array}$ & $\begin{array}{c}\text { Experi- } \\
\text { mental } \\
\text { group No1 } \\
\text { (5\% yeast) }\end{array}$ & $\begin{array}{c}\text { Experi- } \\
\text { mental } \\
\text { group №3 } \\
\text { (15\% yeast) }\end{array}$ \\
\hline $\begin{array}{l}\text { The cost of 1 individuals of } \\
\text { sturgeon, UAH }\end{array}$ & 3.0 & 3.0 & 3.0 & 3.0 & 3.0 & 3.0 \\
$\begin{array}{l}\text { Total spent, prime cost, } \\
\text { UAH }\end{array}$ & 493.68 & 498.24 & 512.11 & 486.85 & 500.04 & 509.14 \\
Attributable profit, UAH & 699.0 & 741.0 & 654.0 & 804.0 & 873.0 & 876.0 \\
$\begin{array}{l}\text { Net profit of total, UAH } \\
\text { The prime cost of 1 }\end{array}$ & 205.32 & 242.76 & 141.89 & 319.15 & 372.96 & 366.86 \\
individuals of sturgeon, & 2.12 & 2.01 & 2.35 & 1.81 & 1.72 & 1.74 \\
UAH & 41.59 & 48.72 & 27.7 & 65.14 & 74.59 & 72.01 \\
\hline \begin{tabular}{l} 
Profitability, \% \\
\hline
\end{tabular}
\end{tabular}

Thus, the level of profitability was directly related to the net profit and prime cost of 1 grown individuals of Russian sturgeon. A comparison of different feeding options for early juveniles of Russian sturgeon allows us to conclude that the highest (over $70 \%$ ) profitability can be achieved with the use of $5 \%$ and $15 \%$ of inactivated baker's yeast in the main feed, while increasing the share of this dietary supplement to $40 \%$ leads to lower rates, even for those in the control groups. A similar relationship was observed for net and other varieties of income.

Thus, the optimal ratio of basic feed and biologically active additives can increase the efficiency of RAS in general, and can indirectly contribute to the development of sturgeon farming in Ukraine, because it increases the profits and incomes of producers.

\section{CONCLUSION AND PERSPECTIVES OF FURTHER DEVELOPMENT}

Thus, the use of inactivated baker's yeast in the feeding of early juveniles of Russian sturgeon grown in RASs is economically feasible if the optimal ratio of this biologically active additive is chosen. The introduction of $5 \%$ and $15 \%$ of inactivated baker's yeast into the diet is cost-effective and economic efficient. These concentrations allow achieving a level of profitability of more than $70 \%$ and reduce the cost of 1 individual to 1.72-1.74 $\mathrm{UAH}$, thus providing, among other feeding options, such parameters as net (372.96 UAH and $366.86 \mathrm{UAH})$ and conditional profit (UAH 873.0 and UAH 876.0), taking into account that when they are used, the share of total feed costs increases to $8-10 \%$ versus $6-7 \%$ when fish are fed exclusively with a starting feed. 


\section{BIBLIOGRAPHY}

1. Козлов В. И., Козлов А. В. Осетроводство. Москва : МГУТУ, 2011. 336 с.

2. Муквич М. Г. Сучасний стан, проблеми та завдання розвитку рибництва в Україні // Рибогосподарська наука України. 2009. № 1. С. 4-8.

3. Стан запасів осетрових риб та розвиток осетрової аквакультури в Україні / Третяк О. М. та ін. // Рибогосподарська наука України. 2010. № 4. С. 4-22.

4. Симон М. Ю. Використання кормових дріжджів у годівлі осетрових видів риб (Acipenseridae) (Огляд) // Рибогосподарська наука України. 2015. № 4(34). С. $100-126$.

5. Третяк О. М. Економічна ефективність ставового рибництва з використанням у полікультурі американського веслоноса // Рибогосподарська наука України. 2010. № 1. С. 112-122.

6. Механізми забезпечення прибутковості рибних господарств України / Смирнюк Н. І. та ін. // Рибогосподарська наука України. 2009. № 1. С. 107115.

7. Лукошкин С. А., Казанов Д. Х. Основные технико-экономические показатели, применяемые в рыбном хозяйстве. Москва : Пищевая промышленность, 1977. $88 \mathrm{c.}$

8. Фридман И. Л. Методические рекомендации по определению экономического эффекта мероприятий по рыбоводству и сырьевой базе пресноводных водоёмов. Ленинград : ГосНИОРХ, 1986. 87 с.

9. Мошенський С. 3., Олійник О. В. Економічний аналіз. Житомир : Рута, 2007. $704 \mathrm{c}$.

\section{REFERENCES}

1. Kozlov, V. I., \& Kozlov, A. V. (2011). Osetrovodstvo. Moskva: MGUTU.

2. Mukvych, M. H. (2009). Suchasnyi stan, problemy ta zavdannia rozvytku rybnytstva v Ukraini. Rybohospodarska nauka Ukrainy, 1, 4-8.

3. Tretiak, O. M., et al. (2010). Stan zapasiv osetrovykh ryb ta rozvytok osetrovoi akvakultury v Ukraini. Rybohospodarska nauka Ukrainy, 4, 4-22.

4. Simon, M. Yu. (2015). Vykorystannia kormovykh drizhdzhiv u hodivli osetrovykh vydiv ryb (Acipenseridae) (Ohliad). Rybohospodarska nauka Ukrainy, 4(34), 100126.

5. Tretiak, O. M. (2010). Ekonomichna efektyvnist stavovoho rybnytstva z vykorystanniam u polikulturi amerykanskoho veslonosa. Rybohospodarska nauka Ukrainy, 1, 112-122.

6. Smyrniuk, N. I., et al. (2009). Mekhanizmy zabezpechennia prybutkovosti rybnykh hospodarstv Ukrainy. Rybohospodarska nauka Ukrainy, 1, 107-115.

7. Lukoshkin, S. A., \& Kazanov, D. Kh. (1977). Osnovnye tekhniko-ekonomicheskie pokazateli, primenyaemye $v$ rybnom khozyaystve. Moskva: Pishchevaya promyshlennost's.

8. Fridman, I. L. (1986). Metodicheskie rekomendatsii po opredeleniyu ekonomicheskogo effekta meropriyatiy po rybovodstvu $i$ syr'evoy baze presnovodnykh vodoemov. Leningrad : GosNIORKh.

9. Moshens'kiy, S. Z., \& Oliynik, O. V. (2007). Ekonomichniy analiz. Zhitomir: Ruta. 